\title{
PENGARUH KEPEMILIKAN MANAJERIAL, KEPEMILIKAN INSTITUSIONAL, STRUKTUR MODAL, PERTUMBUHAN PERUSAHAAN DAN PROFITABILITAS TERHADAP NILAI PERUSAHAAN PADA PERUSAHAAN MANUFAKTUR DI INDONESIA TAHUN 2015-2018
}

\author{
Nursanita $^{1}$, Faris Faruqi ${ }^{2}$, S. Rahayu ${ }^{3}$ \\ Sekolah Tinggi Ilmu Ekonomi Indonesia \\ Jl. Kayu Jati Raya No. 11A, Rawamangun - Jakarta 13220, Indonesia \\ nursanita1@gmail.com ${ }^{2}$, faris.faruqi@gmail.com ${ }^{3}$
}

\begin{abstract}
Abstrak - Penelitian ini bertujuan untuk menguji pengaruh kepemilikan manajerial, kepemilikan institusional, struktur modal, pertumbuhan perusahaan dan profitabilitas terhadap nilai perusahaan pada perusahaan manufaktur yang terdaftar di Bursa Efek Indonesia (BEI). Penelitian ini menggunakan 27 perusahaan manufaktur yang terdaftar di Bursa Efek Indonesia yang dipilih dengan menggunakan metode purposive sampling selama tahun 2015 sampai dengan tahun 2018. Jenis penelitian ini adalah kausalitas kuantitatif, yang dianalisis dengan menggunakan metode analisis regresi linier berganda data panel dengan bantuan alat Eviews 11 untuk mengolah datanya. Hasil penelitian menunjukkan bahwa profitabilitas berpengaruh positif signifikan terhadap nilai perusahaan, semakin besar keuntungan yang diperoleh semakin besar pula kemampuan perusahaan membayarkan devidennya. Hal tersebut dapat memberi sinyal positif kepada investor sehingga saham akan semakin diminati yang kemudian akan meningkatkan nilai perusahaan tersebut.
\end{abstract}

Kata Kunci : Kepemilikan Manajerial, Kepemilikan Institusional, Struktur Modal, Pertumbuhan Perusahaan, Profitabilitas, dan Nilai Perusahaan.

\section{PENDAHULUAN}

Semakin berkembangnya dunia usaha, semakin banyak pula perusahaan yang bermunculan sehingga menimbulkan persaingan yang ketat. Akibat persaingan yang ada membuat perusahaan semakin meningkatkan kinerja agar tujuannya dapat tetap 
tercapai. Berdirinya sebuah perusahaan harus memiliki tujuan yang jelas. Tujuan jangka panjang perusahaan adalah untuk mengoptimalkan nilai perusahaan. Tingginya nilai perusahaan dapat menggambarkan kesejahteraan pemilik perusahaan. Nilai perusahaan akan terlihat dari harga sahamnya. Salah satu faktor yang mempengaruhi nilai perusahaan adalah struktur kepemilikan manajerial dan struktur kepemilikan institusional.

Kepemilikan saham manajemen adalah proporsi saham biasa yang dimiliki oleh para manajemen. Adanya kepemilikan manajemen akan menimbulkan suatu pengawasan terhadap kebijakan-kebijakan yang akan diambil oleh manajemen perusahaan. Dengan kepemilikan saham oleh manajerial, diharapkan manajer akan bertindak sesuai dengan keinginan para principal karena manajer akan termotivasi untuk meningkatkan kinerja dan nantinya dapat meningkatkan nilai perusahaan. Empiris bukti menunjukkan bahwa struktur kepemilikan manajerial mempengaruhi nilai perusahaan. Bukti tidak konsisten dengan temuan yang membuktikan bahwa struktur kepemilikan manajerial tidak berpengaruh pada nilai perusahaan.

Struktur kepemilikan lain yaitu kepemilikan institusional, dimana umumnya dapat bertindak sebagai pihak yang memonitor perusahaan. Semakin besar kepemilikan intitusional maka semakin efisien pemanfaatan aktiva perusahaan dan diharapkan juga dapat bertindak sebagai pencegahan terhadap pemborosan yang dilakukan oleh manajemen. Empiris bukti menunjukkan bahwa struktur kepemilikan institusional berpengaruh positif terhadap nilai perusahaan. Bukti tidak konsisten dengan temuan yang membuktikan bahwa struktur kepemilikan tidak berpengaruh pada nilai perusahaan.

Saat ini dunia usaha tergantung pada masalah pendanaan, beberapa perusahaan mengalami kemunduran karena struktur modal tidak mengalami penyesuaian atau suitability antara cara pemenuhan dana dengan jangka waktu kebutuhannya. Perusahaan-perusahaan tersebut harus menanggung modal yang besar dikarenakan pendanaan dari unsur hutang lebih besar daripada modal sendiri, sehingga penggunaan dana yang digunakan untuk aktivitas operasional perusahaan lebih banyak menggunakan dari unsur hutang. Mengantisipasi hal tersebut, manajer keuangan perusahaan harus berhati-hati dalam menetapkan struktur modal yang diharapkan perusahaan dapat meningkatkan nilai perusahaan lebih unggul dalam menghadapi 
persaingan bisnis, menghitung profitabilitas dan melakukan pengelolaan struktur biaya dalam perusahaan. Empiris bukti menunjukkan bahwa struktur modal berpengaruh positif terhadap nilai perusahaan. Bukti tidak konsisten dengan temuan yang membuktikan bahwa struktur modal tidak berpengaruh pada nilai perusahaan.

Pertumbuhan (Growth) adalah seberapa jauh perusahaan menempatkan diri dalam sistem ekonomi secara keseluruhan atau sistem ekonomi untuk industri yang sama. Pada umumnya, perusahaan yang tumbuh dengan cepat memperoleh hasil positif dalam artian pemantapan posisi di peta persaingan, menikmati penjualan yang meningkat secara signifikan dan diiringi oleh adanya peningkatan pangsa pasar. Perusahaan yang tumbuh cepat juga menikmati keuntungan dari citra positif yang diperoleh, akan tetapi perusahaan harus ekstra hati-hati karena kesuksesan yang diperoleh menyebabkan perusahaan menjadi rentan terhadap adanya isu negatif. Empiris bukti menunjukkan bahwa pertumbuhan perusahaan berpengaruh positif terhadap nilai perusahaan. Bukti tidak konsisten dengan temuan yang membuktikan bahwa pertumbuhan perusahaan tidak berpengaruh pada nilai perusahaan.

Profitabilitas merupakan aspek penting bagi perusahaan untuk mempertahankan keberlangsungan hidup usahanya dalam jangka panjang, karena profitabilitas menunjukkan apakah suatu badan usaha memiliki prospek yang baik dimasa depan. Dengan demikian, suatu perusahaan akan selalu berusaha dalam meningkatkan profitabilitas, karena semakin tinggi tingkat profitabilitas maka akan semakin terjamin keberlangsungan hidup perusahaan tersebut. Empiris bukti menunjukkan bahwa profitabilitas berpengaruh positif terhadap nilai perusahaan. Bukti tidak konsisten dengan temuan yang membuktikan bahwa profitabilitas tidak berpengaruh pada nilai perusahaan.

Ketidakkonsistenan dari beberapa hasil temuan diatas memotivasi peneliti untuk melakukan pemeriksaan ulang kausalitas antara variabel yang digunakan dalam penelitian ini dengan memperluas studi sebelumnya menganalisis pengaruh pertumbuhan perusahaan, struktur modal, dan profitabilitas terhadap nilai perusahaan dalam perusahaan manufaktur sektor industri barang konsumsi yang terdaftar di Bursa Efek Indonesia (BEI) pada periode tahun 2013-2015, dengan menambahkan variabel kepemilikan manajerial dan kepemilikan institusional. Perbedaan lain dari penelitian ini dengan penelitian sebelumnya adalah waktu pengamatan, variabel penelitian, dan 
objek, yang mencakup seluruh sektor perusahaan manufaktur di Indonesia pada tahun 2015-2018.

\section{TINJAUAN PUSTAKA DAN PENGEMBANGAN HIPOTESIS}

\subsection{Teori Keagenan}

Teori keagenan menjelaskan mengenai hubungan antara pemegang saham sebagai prinsipal dan manajemen sebagai agen. Manajemen merupakan pihak yang dikontrak oleh pemegang saham yang bekerja demi kepentingan pemegang saham. Hal tersebut yang membuat manajemen harus mempertanggungjawabkan semua pekerjaannya kepada pemegang saham. Jika kedua belah pihak mempunyai tujuan yang sama untuk memaksimumkan nilai perusahaan, maka diyakini agen akan bertindak dengan cara yang sesuai dengan kepentingan pemegang saham (Jensen and Meckling, 1976. 5).

Kontrak kerja yang terdapat dalam teori agensi disebut dengan "nexus of contract”. Kontrak kerjasama ini berisi kesepakatan yang menjelaskan bahwa pihak manajemen perusahaan harus bekerja secara maksimal, namun pada kenyataannya sikap opportunistic di kalangan manajemen perusahaan masih sering terjadi. Pihak agen memiliki informasi secara maksimal (full information) sedangkan pihak prinsipal memiliki keunggulan kekuasaan (discretionary power). Hal tersebut berarti kedua belah pihak ini sama-sama memiliki kepentingan pribadi (self-interest) dalam setiap keputusan yang diambil. Salah satu efek yang jauh bisa terjadi adalah perolehan dividen yang rendah yang akan diterima oleh prinsipal karena faktor permainan yang dilakukan oleh agen (Fahmi, 2014. 19).

Atas perbedaan kepentingan antara prinsipal dan agen akan menimbulkan masalah keagenan (agency problem). Manajer cenderung lebih mengutamakan kepentingannya sendiri daripada kepentingan pemegang saham. Pengawasan dan pemantauan dalam mengurangi konflik antara manajemen dan pemegang saham akan menimbulkan biaya. Agency cost adalah biaya yang dikeluarkan oleh pemilik perusahaan guna meningkatkan nilai perusahaan (Hariyanto dan Lestari, 2015.1606). Masalah keagenan dapat diatasi melalui sistem pengawasan yang mampu menyamakan kepentingan antara pemegang saham dengan manajemen. Masalah keagenan diharapkan dapat diatasi dengan struktur kepemilikan. Struktur kepemilikan terdiri dari kepemilikan manajerial dan kepemilikan institusional. 


\subsection{Teori Sinyal}

Teori sinyal (signaling theory) pertama kali diperkenalkan oleh Spence di dalam penelitiannya yang berjudul Job Market Signaling. Spence (1973) mengemukakan bahwa isyarat atau signal memberikan suatu sinyal, pihak pengirim (pemilik informasi) berusaha memberikan potongan informasi relevan yang dapat dimanfaatkan oleh pihak penerima. Pihak penerima kemudian akan menyesuaikan perilakunya sesuai dengan pemahamannya terhadap sinyal tersebut.

Dalam kerangka teori sinyal disebutkan bahwa dorongan perusahaan untuk memberikan informasi adalah karena terdapat asimetri informasi antara perusahaan dan pihak luar, hal ini disebabkan karena perusahaan mengetahui lebih banyak informasi perusahaan dan prospek yang akan datang dibandingkan pihak luar (investor dan kreditur). Salah satu cara yang dapat dilakukan oleh perusahaan untuk meningkatkan nilai perusahaan dengan mengurangi asimetri informasi tersebut adalah dengan memberikan sinyal pada pihak luar. Pada waktu informasi diumumkan dan semua pelaku pasar sudah menerima informasi tersebut, pelaku pasar terlebih dahulu menginterpretasikan dan menganalisis informasi tersebut sebagai sinyal baik (good news) atau sinyal buruk (bad news). Jika pengumuman informasi tersebut sebagai sinyal baik bagi investor, maka terjadi perubahan dalam volume perdagangan saham.

\section{Kepemilikan Manajerial dan Nilai Perusahaan}

Kepemilikan manajerial adalah pihak manajemen yang secara aktif ikut dalam pengambilan keputusan perusahaan (manajer, direktur dan komisaris) dan juga diberikan kesempatan untuk ikut memiliki saham perusahaan (pemegang saham). Peningkatan kepemilikan manajerial dapat menyejajarkan kepentingan antara manajer dan pemegang saham sehingga manajer cenderung akan bertindak sesuai dengan kebutuhan pemegang saham.

Hasil penelitian dari Nugroho (2014) menyatakan bahwa kepemilikan manajerial tidak berpengaruh terhadap nilai perusahaan karena rendahnya kepemilikan saham oleh manajemen membuat kinerja manajemen cenderung rendah sehingga tidak mempengaruhi nilai perusahaan. Berdasarkan uraian diatas, maka hipotesis dalam penelitian ini adalah:

H1: Kepemilikan manajerial tidak berpengaruh terhadap nilai perusahaan. 


\section{Kepemilikan Institusional dan Nilai Perusahaan}

Kepemilikan institusional merupakan proporsi kepemilikan saham oleh institusi dalam hal ini institusi pendiri perusahaan, bukan institusi pemegang saham publik yang diukur dengan persentase jumlah saham yang dimiliki oleh investor institusi intern. Semakin tinggi kepemilikan institusional maka keberadaan investor institusional untuk memantau perilaku manajemen akan semakin efektif yang menimbulkan penggunaan utang menurun karena manajemen akan semakin berhati-hati dalam memperoleh pinjaman sebab utang yang tinggi dapat menyebabkan perusahaan mengalami gagal bayar dan berakhir pada kebangkrutan.

Hasil penelitian dari Yuslirizal (2017) menyatakan bahwa kepemilikan institusional berpengaruh positif dan signifikan terhadap nilai perusahaan karena dengan adanya kepemilikan institusional akan mendorong peningkatan pengawasan yang lebih optimal. Berdasarkan uraian diatas, maka hipotesis dalam penelitian ini adalah:

H2: Kepemilikan institusional berpengaruh positif terhadap nilai perusahaan.

\section{Struktur Modal dan Nilai Perusahaan}

Struktur modal adalah gambaran dari bentuk proporsi finansial perusahaan yaitu antara modal yang bersumber dari hutang jangka panjang dan modal sendiri yang dijadikan sumber pembiayaan suatu perusahaan. Perusahaan dengan tingkat pengembangan usaha yang baik dalam jangka panjang akan memberikan keuntungan yang besar kepada investor. Struktur modal yang optimal yang secara langsung akan mempengaruhi nilai perusahaan.

Hasil penelitian dari Dhani dan Utama (2017) menyatakan bahwa struktur modal tidak berpengaruh terhadap nilai perusahaan karena semakin tinggi struktur modal tidak berpengaruh dalam peningkatan nilai perusahaan. Berdasarkan uraian diatas, maka hipotesis dalam penelitian ini adalah:

H3: Struktur modal tidak berpengaruh terhadap nilai perusahaan.

\section{Pertumbuhan Perusahaan dan Nilai Perusahaan}

Pertumbuhan perusahaan adalah seberapa jauh perusahaan menempatkan diri dalam sistem ekonomi secara keseluruhan atau sistem ekonomi untuk industri yang sama. Pertumbuhan perusahaan sangat diharapkan oleh pihak internal maupun eksternal suatu perusahaan karena dapat memberikan suatu aspek yang positif bagi mereka. Dari 
sudut pandang investor, pertumbuhan suatu perusahaan merupakan tanda bahwa perusahaan memiliki aspek yang menguntungkan, dan mereka mengharapkan tingkat pengembalian dari investasi mereka memberikan hasil yang lebih baik.

Hasil penelitian dari Suastini et al., (2016) juga sama menyebutkan bahwa pertumbuhan perusahaan berpengaruh positif dan signifikan terhadap nilai perusahaan. Perusahaan yang terus tumbuh umumnya akan memiliki prospek yang baik, hal ini tentu akan direspon positif oleh para investor sehingga akan berpengaruh pada peningkatan nilai perusahaan. Berdasarkan uraian diatas, maka hipotesis dalam penelitian ini adalah:

H4: Pertumbuhan perusahaan berpengaruh positif terhadap nilai perusahaan.

\section{Profitabilitas dan Nilai Perusahaan}

Profitabilitas adalah kemampuan suatu perusahaan untuk memperoleh laba (keuntungan) dalam waktu tertentu. Semakin tinggi profitabilitas perusahaan, akan membuat investor menjadi percaya untuk menanamkan modalnya pada perusahaan tersebut. Profitabilitas yang baik pun akan memberikan keuntungan bagi pihak perusahaan dalam kaitannya dengan penambahan dana untuk kegiatan operasinya dan bagi pihak investor dalam hal mendapatkan keuntungan dari investasi tersebut.

Hasil penelitian dari Dewi et al., (2014) menyatakan bahwa profitabilitas berpengaruh secara positif dan signifikan terhadap nilai perusahaan. Hal ini berarti semakin tinggi ROE maka semakin tinggi juga price book value sebagai ukuran dari nilai perusahaan karena investor akan membeli saham-saham dan akan lebih tertarik dengan return on equity atau bagian dari total profitabilitasnya ke pemegang saham. Berdasarkan uraian diatas, maka hipotesis dalam penelitian ini adalah:

H5: Profitabilitas berpengaruh positif terhadap nilai perusahaan.

\section{METODA PENELITIAN}

Penelitian ini menerapkan pendekatan kuantitatif karena data yang digunakan adalah data sekunder. Penelitian ini menggunakan hubungan kausalitas yang menjelaskan mengenai hubungan sebab-akibat antara variabel dependen dengan variabel independen. Populasi dalam penelitian ini adalah perusahaan Manufaktur yang terdaftar di Bursa Efek Indonesia (BEI) pada tahun 2015-2018, sedangkan sampel yang digunakan dalam penelitian ini dipilih dengan menggunakan teknik purposive sampling 
method yang diperoleh sebanyak 27 perusahaan. Metode analisis yang dilakukan dalam penelitian ini menggunakan metode analisis regresi linier berganda data panel dengan bantuan alat Eviews 11, persamaan regresi berganda dalam penelitian ini dapat disajikan sebagai berikut:

$$
P B V=\alpha+\beta_{1} K M+\beta_{2} K I+\beta_{3} D E R+\beta_{4} P L+\beta_{5} R O E+\varepsilon_{i t}
$$

Keterangan:

$\begin{array}{ll}\text { PBV } & =\text { Nilai Perusahaan } \\ \alpha & =\text { Konstan } \\ \beta & =\text { Koefisien Regresi } \\ \text { KM } & =\text { Kepemilikan Manajerial } \\ \text { KL } & =\text { Kepemilikan Institusional } \\ \text { DER } & =\text { Struktur Modal } \\ \text { PL } & =\text { Pertumbuhan Perusahaan } \\ \text { ROE } & =\text { Profitabilitas } \\ \text { e } & =\text { Error }\end{array}$

\section{HASIL DAN PEMBAHASAN}

\subsection{Statistik Deskriptif}

Statistik deskriptif memberikan gambaran atau deskripsi suatu variabel yang digunakan dalam penelitian ini. Berikut adalah deskripsi mengenai Nilai Perusahaan (PBV) sebagai variabel dependen dan Kepemilikan Manajerial (KM), Kepemilikan Institusional (KI), Struktur Modal (DER), Pertumbuhan Perusahaan (PL), dan Profitabilitas (ROE) sebagai variabel independen. Tujuan analisis ini adalah untuk memberikan gambaran umum mengenai nilai rata-rata (mean), maksimum, minimum, dan standar deviasi masing-masing variabel tersebut. Data diolah dengan software Eviews 11 sehingga diperoleh hasil seperti yang telah disajikan pada tabel 4.1 sebagai berikut: 
Tabel 4.1.

Analisis Statistik Deskriptif Variabel Penelitian

Descriptive Statistics

\begin{tabular}{|l|l|l|l|l|l|l|}
\hline & \multicolumn{1}{|c|}{ PBV } & \multicolumn{1}{c|}{ KM } & \multicolumn{1}{c|}{ KI } & \multicolumn{1}{c|}{ DER } & \multicolumn{1}{c|}{ CG } & \multicolumn{1}{c|}{ ROE } \\
\hline Mean & 1.814058 & 0.073211 & 0.646425 & 0.833430 & 0.114424 & 0.106239 \\
\hline Median & 1.180999 & 0.026598 & 0.655401 & 0.634503 & 0.071916 & 0.100633 \\
\hline Maximum & 6.724245 & 0.572603 & 0.960912 & 4.546886 & 0.638510 & 0.320297 \\
\hline Minimum & 0.000550 & $7.65 \mathrm{E}-06$ & 0.051432 & 0.124837 & -0.105160 & 0.001008 \\
\hline Std. Dev. & 1.565161 & 0.113052 & 0.196697 & 0.773010 & 0.150785 & 0.071214 \\
\hline
\end{tabular}

Sumber : Olah Data Sekunder

Berdasarkan tabel 4.1 apabila dilihat pada besarnya standar deviasi yang mencerminkan sebaran data maka data PBV memiliki standar deviasi tertinggi yaitu sebesar 1.5651 dan profitabilitas memiliki standar deviasi terendah yaitu 0.07121. Tingginya nilai standar deviasi menunjukkan bahwa data PBV lebih tersebar daripada data lainnya.

\subsection{Pengujian Model Common Effect, Fixed Effect dan Random Effect}

Dalam penelitian ini dilakukan pengujian dengan menggunakan teknik yang bisa digunakan untuk mengestimasi model regresi dengan data panel antara Common Effect, Fixed Effect dan Random Effect. Pengujian dilakukan untuk menentukan teknik yang paling tepat yang akan digunakan untuk melihat pengaruh kepemilikan manajerial, kepemilikan institusional, struktur modal, pertumbuhan perusahaan, dan profitabilitas terahadap nilai perusahaan pada perusahaan manufaktur di Indonesia tahun 2015-2018. Penentuan model yang tepat akan didasarkan pada seberapa besar variabel independen mampu mempengaruhi variabel dependen (R-squared).

\section{Uji Chow}

Tabel 4.2.Uji Chow

\begin{tabular}{lrrr} 
Redundant Fixed Effects Tests & & & \\
Equation: Untitled & & & \\
Test cross-section fixed effects & Statistic & d.f. & Prob. \\
\hline \hline Effects Test & 18.502804 & $(26,76)$ & 0.0000 \\
\hline \hline Cross-section F & 215.131981 & 26 & 0.0000 \\
Cross-section Chi-square & & & \\
\hline \hline
\end{tabular}

Sumber : Olah Data Sekunder

Hasil nilai dari uji chow ini dapat dilihat pada baris Cross-Section Chi-Square kolom Prob., dimana nilainya adalah $0,0000<0,05$ maka model yang dipilih adalah 


\section{Fixed Effect.}

\section{Uji Hausman}

Tabel 4.3.Uji Hausman

\begin{tabular}{l} 
Correlated Random Effects - Hausman Test \\
Equation: Untitled \\
Test cross-section random effects \\
\hline \hline Test Summary \\
\hline \hline Cross-section random
\end{tabular}

Hasil nilai dari uji hausman ini dapat dilihat pada baris Cross-Section Random kolom Prob., dimana nilainya adalah 0,0024 < 0,05 maka model yang dipilih adalah Fixed Effect.

Dari kedua uji yang telah dilakukan untuk memilih model manakah yang paling tepat digunakan dalam mengestimasti data panel dalam penelitian ini, maka dapat disimpulkan bahwa model yang paling tepat digunakan adalah model Fixed Effect. Hal ini dapat dilihat dari hasil pengujian masing - masing. Dari hasil uji Chow yang dilakukan untuk memilih antara model Common Effect atau Fixed Effect, menunjukkan hasil yang terpilih adalah model Fixed Effect. Kemudian, dari hasil uji Hausman yang dilakukan untuk memilih antara model Fixed Effect atau Random Effect menunjukkan hasil yang terpilih adalah model Fixed Effect.

\subsection{Pengujian Hipotesis}

\section{Tabel. 4.9.}

Analisis Regresi Data Panel Dengan Model Fixed Effect

Dependent Variable: $\mathrm{Y}$

Method: Panel Least Squares

Date: 07/26/19 Time: 20:25

Sample: 20152018

Periods included: 4

Cross-sections included: 27

Total panel (balanced) observations: 108

\begin{tabular}{crrrr}
\hline \hline Variable & Coefficient & Std. Error & t-Statistic & Prob. \\
\hline \hline C & 3.317766 & 1.190327 & 2.787273 & 0.0067 \\
KM & -3.157961 & 1.893448 & -1.667837 & 0.0995 \\
KI & -2.903871 & 1.699565 & -1.708596 & 0.0916 \\
DER & 0.273931 & 0.259801 & 1.054387 & 0.2950
\end{tabular}




\begin{tabular}{lrrrr}
\multicolumn{1}{c}{ CG } & -0.012103 & \multicolumn{1}{c}{0.430903} & -0.028087 & 0.9777 \\
& 3.555273 & 1.537671 & 2.312116 & 0.0235 \\
\hline \hline & & & & \\
\hline \hline Cros & & & & \\
\hline \hline Root MSE & & & & \\
Mean dependent var & 0.415658 & R-squared & 0.928814 \\
S.D. dependent var & 1.814058 & Adjusted R-squared & 0.899778 \\
Akaike info criterion & 1.565161 & S.E. of regression & 0.495497 \\
Schwarz criterion & 1.674684 & Sum squared resid & 18.65933 \\
Hannan-Quinn criter. & 2.469390 & Log likelihood & -58.43296 \\
Durbin-Watson stat & 1.996909 & F-statistic & 31.98798 \\
& 2.443192 & Prob(F-statistic) & 0.000000 \\
\hline \hline
\end{tabular}

Sumber : Olah Data Sekunder

Koefisien determinasi pada nilai Adjusted R-squared sebesar 0,8998. Hal ini menunjukkan bahwa sebesar 89,98\% variasi dari nilai perusahaan dapat dijelaskan oleh variabel kepemilikan manajerial, kepemilikan institusional, struktur modal, pertumbuhan perusahaan dan profitabilitas. Sedangkan sisanya sebesar 10,02\% dijelaskan oleh variabel lain diluar penelitian ini.

\section{H1: Kepemilikan Manajerial Tidak Berpengaruh Terhadap Nilai Perusahaan}

Dari hasil uji yang telah dilakukan sebelumnya pada tabel 4.12 diketahui bahwa kepemilikan manajerial menunjukkan nilai t-statistic sebesar -1.6678 dengan nilai probabilitas sebesar 0,0995 dimana nilai tersebut lebih besar dari 0,05 $(0,0995>0,05)$ sehingga dapat disimpulkan bahwa hipotesis H1 diterima. Maka dapat disimpulkan bahwa kepemilikan manajerial tidak berpengaruh terhadap nilai perusahaan. Hasil penelitian menunjukkan kepemilikan manajerial belum tentu dapat membuat manajer bekerja lebih efektif dan efisien guna meningkatkan kinerja perusahaan sehingga tidak mampu meningkatkan nilai perusahaan. Hal tersebut terjadi karena proporsi saham yang dimiliki oleh manajer relatif kecil dan hanya berperan sebagai pemegang saham minoritas di dalam perusahaan sehingga manajer tidak memiliki kendali atas perusahaan. Perusahaan akan otomatis dikendalikan oleh pemegang saham yang memiliki saham mayoritas di perusahaan, sehingga keputusan manajer tidak berpengaruh terhadap kinerja perusahaan. Oleh karena itu, kepemilikan manajerial tidak berpengaruh terhadap nilai suatu perusahaan.

\section{H2: Kepemilikan Institusional Berpengaruh Positif Terhadap Nilai Perusahaan}

Dari hasil uji yang telah dilakukan sebelumnya pada tabel 4.12 diketahui bahwa 
kepemilikan institusional menunjukkan nilai t-statistic sebesar -1.7086 dengan nilai probabilitas sebesar 0,0916 dimana nilai tersebut lebih besar dari 0,05 $(0,0916>0,05)$ sehingga dapat disimpulkan bahwa hipotesis H2 ditolak. Maka dapat disimpulkan bahwa kepemilikan institusional tidak berpengaruh terhadap nilai perusahaan.

Kepemilikan institusional umumnya bertindak sebagai pihak yang mengawasi kinerja perusahaan. Pengawasan terlalu disiplin dan ketat oleh pihak insitusi juga akan membuat manajer merasa tidak nyaman dan akan menurunkan kinerja perusahaan, sehingga harga saham perusahaan menurun dan berdampak pada nilai perusahaan menurun.

\section{H3: Struktur Modal Tidak Berpengaruh Terhadap Nilai Perusahaan}

Dari hasil uji yang telah dilakukan sebelumnya pada tabel 4.12 diketahui bahwa struktur modal menunjukkan nilai $t$-statistic sebesar 1.0544 dengan nilai probabilitas sebesar 0,2950 dimana nilai tersebut lebih besar dari 0,05 (0,2950>0,05) sehingga dapat disimpulkan bahwa hipotesis H3 diterima. Maka dapat disimpulkan bahwa struktur modal tidak berpengaruh terhadap nilai perusahaan. Struktur modal yang diukur dari debt to equity ratio merupakan rasio keuangan yang menggambarkan kemampuan perusahaan untuk membayar kembali hutang yang ada dengan menggunakan modal sendiri, semakin tinggi nilai ini tentunya semakin berisiko keuangan perusahaan tersebut. Semakin besar debt equity ratio menunjukkan semakin besar biaya yang harus dikeluarkan perusahaan untuk membiayai hutang tersebut. Investor cenderung lebih melihat bagaimana pihak manajemen perusahaan dalam menggunakan dana tersebut secara efektif dan efisien, sehingga struktur modal tidak berpengaruh terhadap nilai perusahaan.

\section{H4: Pertumbuhan Perusahaan Berpengaruh Positif Terhadap Nilai Perusahaan}

Dari hasil uji yang telah dilakukan sebelumnya pada tabel 4.12 diketahui bahwa pertumbuhan perusahaan menunjukkan nilai t-statistic sebesar -0.0281 dengan nilai probabilitas sebesar 0,9777 dimana nilai tersebut lebih besar dari $0,05(0,9777>0,05)$ sehingga dapat disimpulkan bahwa hipotesis H4 ditolak. Maka dapat disimpulkan bahwa pertumbuhan perusahaan tidak berpengaruh terhadap nilai perusahaan. Pertumbuhan perusahaan adalah gambaran tolak ukur keberhasilan perusahaan. Aset adalah aktiva yang dapat digunakan untuk aktivitas operasional perusahaan. Perusahaan yang sedang bertumbuh akan membutuhkan biaya yang cukup besar sehingga investor 
akan lebih tertarik untuk menanamkan modalnya kepada perusahaan yang mapan dan tidak sedang bertumbuh. Oleh karena itu, tingginya tingkat pertumbuhan perusahaan tidak akan mempengaruhi kepercayaan investor sehingga tidak akan berpengaruh pada nilai perusahaan.

\section{H5: Profitabilitas Berpengaruh Positif Terhadap Nilai Perusahaan}

Dari hasil uji yang telah dilakukan sebelumnya pada tabel 4.12 diketahui bahwa profitabilitas menunjukkan nilai $t$-statistic sebesar 2.3121 dengan nilai probabilitas sebesar 0,0235 dimana nilai tersebut lebih besar dari $0,05(0,0235<0,05)$ sehingga dapat disimpulkan bahwa hipotesis H5 diterima. Maka dapat disimpulkan bahwa profitabilitas berpengaruh positif terhadap nilai perusahaan. Return on equity digunakan untuk mengukur kemampuan manajemen dalam mengelola modal dalam menghasilkan keuntungan. Semakin besar keuntungan yang diperoleh semakin besar pula kemampuan perusahaan membayarkan devidennya. Hal tersebut dapat memberi sinyal positif kepada investor sehingga saham akan semakin diminati yang kemudian akan meningkatkan nilai perusahaan tersebut.

\section{SIMPULAN DAN SARAN}

\subsection{Simpulan}

Berdasarkan dari hasil penelitian, analisis serta pembahasan yang telah diuraikan mengenai pengaruh kepemilikan manajerial, kepemilikan institusional, struktur modal, pertumbuhan perusahaan, dan profitabilitas terhadap nilai perusahaan pada perusahaan manufaktur yang terdaftar di Bursa Efek Indonesia, maka dapat diperoleh beberapa kesimpulan sebagai berikut:

1. Kepemilikan manajerial tidak berpengaruh terhadap nilai perusahaan. Kepemilikan manajerial belum tentu dapat membuat manajer bekerja lebih efektif dan efisien guna meningkatkan kinerja perusahaan sehingga tidak mampu meningkatkan nilai perusahaan. Hal tersebut terjadi karena proporsi saham yang dimiliki oleh manajer relatif kecil dan hanya berperan sebagai pemegang saham minoritas di dalam perusahaan sehingga manajer tidak memiliki kendali atas perusahaan. Perusahaan akan otomatis dikendalikan oleh pemegang saham yang memiliki saham mayoritas di perusahaan, sehingga keputusan manajer tidak berpengaruh terhadap kinerja perusahaan. 
2. Kepemilikan institusional tidak berpengaruh terhadap nilai perusahaan. Kepemilikan institusional umumnya bertindak sebagai pihak yang mengawasi kinerja perusahaan. Pengawasan terlalu disiplin dan ketat oleh pihak insitusi juga akan membuat manajer merasa tidak nyaman dan akan menurunkan kinerja perusahaan, sehingga harga saham perusahaan menurun dan berdampak pada nilai perusahaan menurun.

3. Struktur modal tidak berpengaruh terhadap nilai perusahaan. Struktur modal yang diukur dari debt to equity ratio merupakan rasio keuangan yang menggambarkan kemampuan perusahaan untuk membayar kembali hutang yang ada dengan menggunakan modal sendiri, semakin tinggi nilai ini tentunya semakin berisiko keuangan perusahaan tersebut. Semakin besar debt equity ratio menunjukkan semakin besar biaya yang harus dikeluarkan perusahaan untuk membiayai hutang tersebut. Investor cenderung lebih melihat bagaimana pihak manajemen perusahaan dalam menggunakan dana tersebut secara efektif dan efisien.

4. Pertumbuhan perusahaan tidak berpengaruh terhadap nilai perusahaan. Pertumbuhan perusahaan berpengaruh positif terhadap nilai perusahaan. Hal ini dikarenakan pertumbuhan perusahaan adalah gambaran tolak ukur keberhasilan perusahaan. Aset adalah aktiva yang dapat digunakan untuk aktivitas operasional perusahaan. Perusahaan yang sedang bertumbuh akan membutuhkan biaya yang cukup besar sehingga investor akan lebih tertarik untuk menanamkan modalnya kepada perusahaan yang mapan dan tidak sedang bertumbuh. Oleh karena itu, tingginya tingkat pertumbuhan perusahaan tidak akan mempengaruhi kepercayaan investor sehingga tidak akan berpengaruh pada nilai perusahaan.

5. Profitabilitas berpengaruh positif terhadap nilai perusahaan. Return on equity digunakan untuk mengukur kemampuan manajemen dalam mengelola modal dalam menghasilkan keuntungan. Semakin besar keuntungan yang diperoleh semakin besar pula kemampuan perusahaan membayarkan devidennya. Hal tersebut dapat memberi sinyal positif kepada investor sehingga saham akan semakin diminati yang kemudian akan meningkatkan nilai perusahaan tersebut. 


\subsection{Saran}

1. Bagi investor, sebaiknya lebih memperhatikan tingkat profitabilitas perusahaan sebagai bahan pertimbangan untuk mengambil keputusan dalam berinvestasi yang akan menguntungkan. Hal ini dikarenakan profitabilitas memberikan pengaruh positif terhadap nilai perusahaan.

2. Untuk penelitian berikutnya, peneliti bisa memperluas penelitian dengan menghubungkan dengan faktor-faktor lain yang mungkin memiliki pengaruh terhadap nilai perusahaan seperti kebijakan deviden, ukuran perusahaan, kinerja keuangan dan GCG (Good Corporate Governance). Hal ini dimaksudkan agar informasi tentang faktor -faktor yang mempengaruhi nilai perusahaan lebih lengkap dan menyeluruh.

\section{DAFTAR PUSTAKA}

Arviansyah, Yandri. 2013. Pengaruh Struktur Modal, Kinerja Keuangan Perusahaan, Pertumbuhan Perusahaan dan Ukuran Perusahaan Terhadap Nilai Perusahaan Pada Perusahaan Yang Terdaftar di Jakarta Islamic Index (JII). Skripsi.Fakultas Ekonomi dan Bisnis UIN Syarif Hidayatullah Jakarta.

Astuti, Wahyu Nur. 2018. Pengaruh Struktur Modal, Profitabilitas, dan Ukuran Perusahaan Terhadap Nilai Perusahaan (Studi Empiris Pada Perusahaan Manufaktur yang Terdaftar di Bursa Efek Indonesia Tahun 2013-2016). Skripsi.Fakultas Ekonomi dan Bisnis Universitas Muhammadiyah Surakarta.

Ajija, Shochrul R. 2011. Cara Cerdas Menguasai EViews.Salemba Empat. Jakarta.

Basuki, Agus Tri and Prawoto, Nano. 2016. Analisis Regresi Dalam Penelitian Ekonomi \&Bisnis : Dilengkapi Aplikasi SPSS \& EVIEWS. Depok : PT Rajagrafindo Persada.

Borolla, Johanis Darwin. 2011. Analisis Pengaruh Struktur Kepemilikan Terhadap Nilai Perusahaan. ISSN 1411 - 1497 Fakultas Ekonomi Universitas Pattimura Ambon.Vol. 7.No. 1.

Brigham, Eugene F. dan Houston, Joel F. 2001.Manajemen Keuangan. Edisi Kedelapan Buku 2. Jakarta: Erlangga.

Brigham, Eugene F. dan Houston, Joel F. 2014.Dasar-Dasar Manajemen Keuangan.Edisi 11. Jakarta: Salemba Empat. 
Brigham, Eugene F. dan Houston, Joel F. 2016.Dasar-dasar Manajemen Keuangan.Buku 1.Edisi 10.Diterjemahkan oleh Ali Akbar Yulianto. Jakarta: Salemba Empat. Hal.68 dan 69.

D, Ni Putu Wida P. dan Suartana, I Wayan.2014. Pengaruh Kepemilikan Manajerial dan Kepemilikan Institusional Pada Nilai Perusahaan.E-Jurnal Akuntansi Universitas Udayana.Vol. 9.No. 3.

Dewi, Ayu Sri Mahatma, dan Wirajaya, Ary. 2013. Pengaruh Struktur Modal, Profitabilitas dan Ukuran Perusahaan Pada Nilai Perusahaan. E-Jurnal Akuntansi Universitas Udayana.Vol. 4. No. 2: 358-372.

Dewi, Putu Yunita Saputri, Yuniarta, Gede Adi, dan Atmadja, Ananta Wikrama Tungga. 2014. Pengaruh Struktur Modal, Pertumbuhan Perusahaan, dan Profitabilitas Terhadap Nilai Perusahaan Pada Perusahaan LQ 45 di BEI Periode 2008-2012. E-Journal S1 Ak Universitas Pendidikan Ganesha. Vol. 2.No. 1.

Dhani, Isabella Permata, dan Utama, A.A Gde Satia. 2017. Pengaruh Pertumbuhan Perusahaan, Struktur Modal, dan Profitabilitas Terhadap Nilai Perusahaan. Jurnal Riset Akuntansi dan Bisnis Airlangga.Vol. 2. No. 1: 135-148.

Ghozali, Imam. 2013. Aplikasi Analisis Multivariate dengan Program IBM SPSS

21. Edisi 7. Semarang: Badan Penerbit - Universitas Diponegoro.

Ghozali, Imam dan Ratmono, Dwi. 2013. Analisis Multivariate dan Ekonometrika: Teori, Konsep dan Aplikasi dengan Eviews 8. Semarang: Undip.

Gujarati, Damodar N dan dawn C. Porter. 2015. Dasar-Dasar Ekonometrika. Edisi 5 Buku 2.Jakarta: Salemba Empat.

Fahmi, Irham. 2014. Manajemen Keuangan dan Pasar Modal.Edisi 1.Jakarta: Mitra Wacana Media.

Fakhruddin, M. dan Hadianto, M. S. 2001.Perangkat dan Model Analisis Investasi di Pasar Modal. Jakarta: Elex Media Komputindo.

Fau, Nia Rositawati. 2015. Pengaruh Struktur Modal, Pertumbuhan Perusahaan, Ukuran Perusahaan, dan Profitabilitas Terhadap Nilai Perusahaan Pada Perusahaan Manufaktur yang Terdaftar di Bursa Efek Indonesia. Skripsi.Fakultas Ekonomi Universitas Negeri Yogyakarta.

Hair, Joseph F., Jr. William C. Black, Barry J. Babin, dan Rolph E. Anderson. 2014. 
Multivariate Data Analysis. $7^{\text {th }}$ Edition. New York: Pearson Education Limited. Hargiansyah, Rifqi Faisal. 2015. Pengaruh Ukuran Perusahaan, Leverage, dan

Profitabilitas Terhadap Nilai Perusahaan (Studi Empiris Pada Perusahaan Manufaktur Yang Terdaftar di Bursa Efek Indonesia). Jurnal Akuntansi Fakultas Ekonomi Universitas Jember.

Hariyanto, Marina Suzuki dan Putu Vivi Lestari.2015. Pengaruh Struktur Kepemilikan,

IOS, dan ROE Terhadap Nilai Perusahaan pada Perusahaan Food and Beverage.E-Journal Manajemen Unud.Vol. 4. No. 4: 1599-1626.

Hermuningsih, Sri. 2013. Pengaruh Profitabilitas, Growth Opportunity, Struktur Modal Terhadap Nilai Perusahaan Pada Perusahaan Publik di Indonesia. Yogyakarta: University of Sarjanawiyata Taman siswa Yogyakarta.

Jensen, Michael C. dan William H. Meckling. 1976. Theory of The Firm: Managerial Behavior, Agency Costs and Ownership Structure. Journal of Financial Economics.Vol. 3. No. 4: 305-360.

Mardiyati, Umi, Ahmad, Gatot Nazir, dan Putri, Ria. 2012. Pengaruh Kebijakan Dividen, Kebijakan Hutang, dan Profitabilitas Terhadap Nilai Perusahaan Manufaktur yang Terdaftar di Bursa Efek Indonesia Periode 2005-2010. Jurnal Riset Manajemen Sains Indonesia.Vol. 3.No. 1.

Moniaga, Fernandes. 2013. Struktur Modal, Profitabilitas dan Struktur Biaya Terhadap

Nilai Perusahaan Industri Keramik, Porcelen, dan Kaca Periode 2007-2011. Jurnal EMBA. Vol. 1. No. 4: 433-442.

Nugroho, Purwo Adi. 2014. Pengaruh Struktur Kepemilikan Manajerial, Struktur Kepemilikan Institusional, Set Kesempatan Investasi, Ukuran Perusahaan Trhadap Nilai Perusahaan. Jurnal Ilmiah Magister Akuntansi Fakultas Ekonomi dan Bisnis Universitas Airlangga.

Permanasari, Wien Ika. 2010. Pengaruh Kepemilikan Manajemen, Kepemilikan Institusional, dan Corporate Social Responsibility Terhadap Nilai Perusahaan. Skripsi.Fakultas Ekonomi Universitas Diponegoro Semarang.

Puspita, Novita Santi. 2011. Analisis Pengaruh Struktur Modal, Pertumbuhan Perusahaan, Ukuran Perusahaan, dan Profitabilitas Terhadap Nilai Perusahaan Pada Perusahaan Manufaktur yang Terdaftar di Bursa Efek Indonesia Periode 2007-2009. Skripsi.Fakultas Ekonomi Universitas Diponegoro Semarang. 
S, Setiadharma and M, Machali. 2017. The Effect of Asset Structure and Firm Size on Firm Value with Capital Structure as Intervening Variable. Journal Business \& Financial Affairs.Vol. 6.No. 4.

Sekaran, Uma dan Roger Bougie. 2016. Research Methods for Business. $7^{\text {th }}$ Edition. United Kingdom: John Wiley \& Sons Ltd.

Siburian, Nurmy Evitamala. 2017. Analisis Pengaruh Ukuran Perusahaan, Leverage, Kebijakan Dividen, dan Pertumbuhan Perusahaan Terhadap Nilai Perusahaan (Studi Empiris Perusahaan Manufaktur Yang Terdaftar di BEI Periode 20122016). Skripsi.Fakultas Ekonomi dan Bisnis Universitas Sumatera Utara.

Sofyaningsih, Sri dan Hardiningsih, Pancawati. 2011. Struktur Kepemilikan, Kebijakan Dividen, Kebijakan Hutang, dan Nilai Perusahaan. Dinamika Keuangan dan Perbankan. Hal: 68-87.

Soesetio, Yuli. 2007. Kepemilikan Manajerial dan Institusional, Kebijakan Dividen, Ukuran Perusahaan, Struktur Aktiva dan Profitabilitas Terhadap Kebijakan Hutang.Jurnal Bisnis dan Akuntansi.Vol. 11.No. 3.

Spence, Michael. 1973. Job Market Signaling. The Quartely Journal of Economics.Vol. 87.No. 3. (Aug., 1973). Pp. 355-374.

Suastini, Ni Made, Purbawangsa, Ida Bagus Anom, dan Rahyuda, Henny. 2016. Pengaruh Kepemilikan Manajerial dan Pertumbuhan Perusahaan Terhadap Nilai Perusahaan Pada Perusahaan Manufaktur di Bursa Efek Indonesia (Struktur Modal Sebagai Variabel Moderasi).E-Jurnal Ekonomi dan Bisnis Universitas Udayana. Vol. 5 No. 1: 143-172.

Sucuahi, William and Cambarihan, Jay Mark. 2016. Influence of Profitability to the Firm Value of Diversified Companies in the Philippines. Accounting and Finance Research.Vol. 5.No. 2.

Sudana, I Made. 2011. Manajemen Keuangan Perusahaan. Jakarta: Erlangga.

Sugiyono. 2015. Metode Penelitian Manajemen. Edisi 1. Bandung: Penerbit Alfabeta.

Sukirni, Dwi. 2012. Kepemilikan Manajerial, Kepemilikan Institusional, Kebijakan Deviden dan Kebijakan Hutang Analisis Terhadap Nilai Perusahaan. Accounting Analysis Journal.Vol. 1.No. 2.

Susanti, Neneng Lasmita. 2016. Pengaruh Struktur Modal, Pertumbuhan Perusahaan, Profitabilitas, dan Kebijakan Dividen Terhadap Nilai Perusahaan Studi Pada 
Emiten Sektor Manufaktur di BEI. JRAK.Vol. 7. No.2: 43-53.

Tambalean, Friko Allan Kevin, Manossoh, Hendrik, dan Runtu, Treesje. 2018.

Pengaruh Kepemilikan Manajerial dan Kepemilikan Institusional Terhadap

Nilai Perusahaan Pada Perusahaan Sektor Industri Barang Konsumsi di

BEI.Jurnal Riset Akuntansi Going Concern 13(4), 465-473.

Weston, J.F dan Copeland, Thomas. 2001. Manajemen Keuangan. Jilid I. Edisi ke-

9.Jakarta : Binarupa Aksara.

Warapsari, A. A. Ayu Uccahati, dan Suaryana, I G. N. Agung. 2016. Pengaruh Kepemilikan Manajerial dan Institusional Terhadap Nilai Perusahaan dengan Kebijakan Utang Sebagai Variabel Intervening.E-Jurnal Akuntansi Universitas Udayana. Vol. 16 No. 3: 2288-2315.

Widarjono, Agus. 2009. Ekonometrika Pengantar dan Aplikasinya.Edisi Ketiga.

EKONISIA.Yogyakarta.

Wijoyo, Dewi Sari. 2014. Faktor-faktor yang Mempengaruhi Nilai Perusahaan Manufaktur di Bursa Efek Indonesia. Jurnal Bisnis dan Akuntansi.Vol. 16. No. 1a: $31-48$.

Yadnyana, I Ketut dan Wati, Ni Wayan Alit Erlina. 2011. Struktur Kepemilikan, Kebijakan Dividend an Nilai Perusahaan Manufaktur yang Go Public. Jurnal Keuangan dan Perbankan.Vol. 15.No. 1.

Yuslirizal, Andhika. 2017. Pengaruh Kepemilikan Manajerial, Kepemilikan Institusional, Growth, Likuiditas dan Size Terhadap Nilai Perusahaan Pada Industri Tekstil dan Garmen di Bursa Efek Indonesia. E-Journal Katalogis. Vol. 5. No. 3: 116-126. 